\title{
MENGIDENTIFIKASI SIKAP PENDIDIKAN KARAKTER MENGHARGAI PRESTASI TERHADAP SISWA KELAS VIII SMP N 18 KOTA JAMBI
}

\author{
${ }^{1}$ M. Arif Rahman Hakim, ${ }^{2}$ Riko Firmansyah, ${ }^{3}$ Afri Yenil \\ ${ }^{1,2}$ Pendidikan Fisika, FKIP, Universitas Jambi \\ ${ }^{3}$ MTs Negeri 1 Tanjung Jabung Barat
}

Email: ${ }^{1}$ hakimarifrahman06@gmail.com, ${ }^{2}$ Firmansyahriko321@gmail.com, 3afriyeni1010@gmail.com

Tersedia Online di
http://www.jurnal.unublitar.ac.id/
index.php/briliant

\section{Sejarah Artikel}

Diterima pada 24 April 2019

Disetuji pada 26 April 2019

Dipublikasikan pada 22 Mei 2019 Hal. 198-205

\begin{tabular}{l}
\hline Kata Kunci: \\
\hline $\begin{array}{l}\text { Katakter, Menghargai Prestasi, } \\
\text { dan Pendidikan }\end{array}$ \\
\hline
\end{tabular}

DOI:

http://dx.doi.org/10.28926/briliant .v3i4.308

\begin{abstract}
Abstrak: Penelitian ini bertujuan untuk untuk mengetahui bagaimana sikap siswa SMP NEGERI 18 Kota Jambi terhadap Pendidikan Karakter menghargai prestasi. Jenis penelitian ini adalah Deskriptif Statistik, yaitu berupa penggunaan lembar angket berisi pernyataan - pernyataan. Populasi penelitian meliputi kelas VII, VIII, dan IX SMPN 18 Kota Jambi, dengan jumlah keseluruhan 720 siswa. Sampel untuk penelitian menggunakan kelas VIII E dan VIII F, dengan jumlah masing - masing kelas 32 siswa dan 28 siswa. Teknik dalam pengambilan data penelitian dengan cara membagikan lembar angket berisi pernyataan kepada tiap siswa, yang disertai tanggapan-tanggapan yang harus dipilih siswa. Data hasil penelitian yang diperoleh menyatakan bahwa, bahwa siswa kelas VIII E telah memiliki karakter yang baik dalam menghargai prestasi. Sedangkan untuk siswa kelas VIII F, telah memiliki karakter yang sangat baik dalam menghargai prestasi. Dikarenakan pentingnya penerapan pendidikan karakter pada siswa pada setiap jenjang pendidikan. Oleh karena itu, sangat diharapkan adanya peningkatan kesadaran siswa dalam menghargai prestasi.
\end{abstract}

\section{PENDAHULUAN}

Pendidikan adalah pembelajaran pengetahuan suatu individu dan sekelompok orang yang diturunkan ke generasi lainnya melalui pengajaran dan pelatihan. Pendidikan juga sering terjadi di bawah bimbingan guru, orang tua, orang lain dan keluarga, tetapi memungkinkan juga belajar secara otodidak. Selain itu, pendidikan merupakan suatu hal yang sangat menarik untuk dijadikan topik pembicaraan, baik itu dikalangan umum ataupun akademisi. Menurut Sani,(2014:1), pendidikan adalah memberikan kemungkinan pada siswa untuk memperoleh "kesempatan","harapan" dan pengetahuan agar dapat hidup secara lebih baik. Oleh karena itu pendidikan sangat penting di turunkan ke siswa dan generasi penerus masa depan bangsa ini agar menjadi pribadi yang mengetahui adab dan pengetahuan yang tinggi. Menurut Kurniawan, Astalini dan Anggraini (2018) Pendidikan adalah sebuah proses memperbaiki kualitas kehidupan, serta memperoleh dan menanamkan keterampilan yang dilakukan oleh peserta didik. Menurut Nisa (2019) Pendidikan adalah usaha sadar dan terencana untuk mewujudkan suasana belajar agar peserta didik secara aktif mengembangkan potensi dirinya untuk memiliki kekuatan spiritual keagamaan, pengendalian diri, 
kepribadian, kecerdasan, akhlak manusia serta ketrampilan yang diperlukan dirinya, masyarakat bangsa dan negara.

Memasuki abad ke 21, dunia pendidikan mulai beralih dari pendidikan berbasis nilai menjadi pendidikan berbasis karakter. Hal ini dilakukan karena di dalam dunia pendidikan, terdapat banyak peristiwa yang banyak merendahkan harkat dan martabat manusia, dapat dikatakan bahwa pendidikan di Indonesia sedang mengalami krisis karakter. Pendidikan karakter adalah bentuk kegiatan manusia yang di dalamnya terdaat suatu tindakan yang mendidik diperuntukkan bagi generasi selanjutnya. Menurut Kesuma, Triatna, \& Permana (2013:7) dalam Ramdhani (2014:28) mengatakan pendidikan karakter adalah Pengembangan kemampuan pada pembelajaran untuk berperilaku baik yang di tandai dengan perbaikan kemampuan yang akan menjadikan manusia sebagai makhluk yang berketuhanan dan mengemban amanah sebagai pemimpin di dunia. Oleh karena itu tujuan pendidikan karakter ini adalah untuk membentuk individu yang menyempurnakan diri secara terus menerus dan melatih kemampuan diri demi menjadi pribadi yang lebih baik.

Untuk menanggulangi pengikisan karakter peserta didik, maka dibuatlah suatu instrumen pendidikan seperti pemberian angket untuk mengetahui kedalaman karakter peserta didik, mengerahkan pengajar yang telah berpengalaman, memberikan sumber belajar yang jelas, dan memberikan tindakan pembelajaran seperti strategi pembelajaran, metode pembelajaran, dan model pembelajaran yang tepat bagi para peserta didik (Fauzi, dkk., 2017:28). Penilaian karakter bisa muncul dikarenakan belum berhasilnya sistem pendidikan dalam menciptakan berbagai lulusan yang unggul dalam kemampuan kognitif, psikomotorik, dan juga afektif (Febrianshari, dkk., 2018:89). Berhubungan dengan pendidikan karakter ataupun pendidikan moral, pemerintah telah memberikan respon positif dengan diputuskannya Kebijakan Nasional Pembangunan Karakter Bangsa yang berisikan tentang arah kebijakan, tahapan, dan strategi yang digunakan untuk pembangunan karakter bangsa, khususnya para peserta didik (Amir, 2017:128).

Menurut Narwanti (2011:30), dalam Nurjannah (2017), menghargai prestasi adalah perilaku dan karakter yang mendorong dirinya untuk menghasilkan sesuai yang berguna bagi masyarakat, dan mengakui, serta menghormati keberasilan orang lain. Oleh karena itu untuk dapat menghargai prestasi orang lain dengan cara memberikan tepuk tangan ketika pemenang itu di umumkan di depan orang banyak. Dengan cara itu maka akan terbentuk sikap individu yang mampu menyempurnakan dirinya agar menjadi pribadi yang baik dan berguna bagi nusa, bangsa dan agama.

Menurut Kementerian Pendidikan dan Kebudayaan tahun 2013,2014, 2015 dalam Kurniawati dan irsyadillah (2018), nilai menghargai prestasi dapat dilihat dari bentuk pemberian seseorang terhadap seseorang lainnya yang memiliki prestasi. Dalam menghargai prestasi orang lain, seseorang dapat melakukan suatu tindakan berua pujian dan dorongan supaya prestasi yang diperoleh tersebut dapat dipertahankan. Tujuan penelitian, untuk mengetahui bagaimana sikap siswa SMP NEGERI 18 Kota Jambi terhadap Pendidikan Karakter menghargai prestasi, khususnya kelas VIII E dan VIII F. Hasil penelitian yang diperoleh ini dapat berkontribusi bagi penelitian selanjutnya juga bagi sekolah yang diteliti supaya 
guru disekolah mampu meningkatkan sikap siswa terhadap pendidikan karakter menghargai prestasi.

\section{METODE}

Metode yang digunakan dalam melakukan penelitian ini, yakni Descriptive Statistic, merupakan metode dengan instrumen berupa lembar angket yang dibagikan kepada sampel. Untuk penelitian dilakukan di SMP Negeri 18 Kota Jambi, dengan populasi keseluruhan dari kelas VII hingga kelas IX sejumlah 720 siswa. Sedangkan sampel yang digunakan dalam penelitian ini, yaitu kelas VIII E 28 siswa dan VIII F 30 siswa. Pengumpulan data dilakukan melalui pemberian instrument, yaitu angket. Angket ini mempunyai 25 pernyatan sikap, yang semua pernyataan merupakan pernyataan positif.

Tabel 1. Contoh pernyataan sikap menghargai prestasi

\begin{tabular}{|c|c|c|c|c|}
\hline \multirow{2}{*}{ No } & \multirow{2}{*}{ Pernyataan } & \multicolumn{3}{|c|}{ Jawaban } \\
\hline & & $\mathbf{S}$ & SR J & TP \\
\hline 1 & $\begin{array}{l}\text { Saya membuat karya seni/tulis sendiri (tidak } \\
\text { mengambil/menyalin karya orang lain. }\end{array}$ & & & \\
\hline 2 & $\begin{array}{l}\text { Saya mengerjakan sendiri pada waktu ujian atau } \\
\text { ulangan }\end{array}$ & & & \\
\hline 3 & $\begin{array}{l}\text { Saya merasa percaya ketika saya mengungkapkan } \\
\text { pendapat di depan kelas. }\end{array}$ & & & \\
\hline 4 & Saya percaya diri dalam melakukan segala hal. & & & \\
\hline 5 & $\begin{array}{l}\text { Saya percaya diri dalam memberikan penjelasan } \\
\text { kepada teman yang bertanya. }\end{array}$ & & & \\
\hline
\end{tabular}

Sikap siswa pada Pendidikan Karakter menghargai prestasi dalam penelitian ini menggunakan skala Likert. Skala Likert dengan jenis skalanya selalu (S), sering (SR), jarang (J), dan tidak pernah (TP), Setiap item positif dalam instrumen yang memiliki nilai: $\mathrm{S}=4, \mathrm{SR}=3, \mathrm{~J}=2$, dan $\mathrm{TP}=1$. Data angket ini diberikan kepada siswa/i kelas VIII SMP Negeri 18 Kota Jambi. Hasil data penelitian ini di analisis menggunakan aplikasi SPSS. Data peneletian ini berupa data kuantitatif dan di analisis menggunakan dengan menggunakan statistika deskriptif. Pengolahan ini bertujuan untuk melihat sikap siswa SMP NEGERI 18 Kota Jambi terhadap Pendidikan Karakter menghargai prestasi. Khususnya siswa kelas VIII E dan siswa kelas VIII F berdasarkan indikator sikap yang telah ditentukan.

Skala sikap digunakan untuk melihat sikap siswa terhadap objek tertentu, hasil kategori sikap berupa kategori mendukung (positif). Hasil data ini didapatkan dari penyebaran lembar angket penelitian sikap siswa terhadap pendidikan karakter menghargai prestasi yang telah dilakukan pada siswa smp kelas VIII di SMP NEGERI 18 Kota Jambi yang berjumlah 720 siswa. Hasil data angket sikap yang ditampilkan pada analisis data di bawah ini terdiri 2 bagian penilaian. Pertama adalah penilaian berdasarkan interval yang memliki kategori sikap sebagai berikut: sangat buruk, buruk, cukup, baik, sangat baik. Penilaian kategori sikap ini berdasarkan frekuensi dan persentase seluruh siswa yang memilih setiap kategori sikap. Kedua adalah berdasarkan skala sikap. Skala sikap dengan jenis skalanya selalu (S), sering (SR), jarang (J), dan tidak pernah (TP),

200 BRILIANT: Jurnal Riset dan Konseptual Volume 4 Nomor 2, Mei 2019 
Setiap item positif dalam instrumen yang memiliki nilai: $\mathrm{S}=4, \mathrm{SR}=3, \mathrm{~J}=2$, dan $\mathrm{TP}=1$. Penilaian ini berdasarkan jumlah seluruh siswa yang memilih masingmasing skala sikap dan menghasilkan mean, modus, median, standar deviasi, nilai minimu, dan nilai maximu. Kedua penilaian sikap ini didapatkan dengan menggunakan analisis statistik deskriptif dari software pengolahan data aplikasi SPSS.

\section{HASIL}

Untuk data kelas VIII E setelah diolah menggunakan alikasi SPSS, diperoleh nilai mean sebesar 82,3214, modus sebesar 81,00, median sebesar 81,5000 , standar deviasi sebesar 5,44368 dengan nilai terendahnya adalah 70,00 dan nilai tertinggi 94,00 .

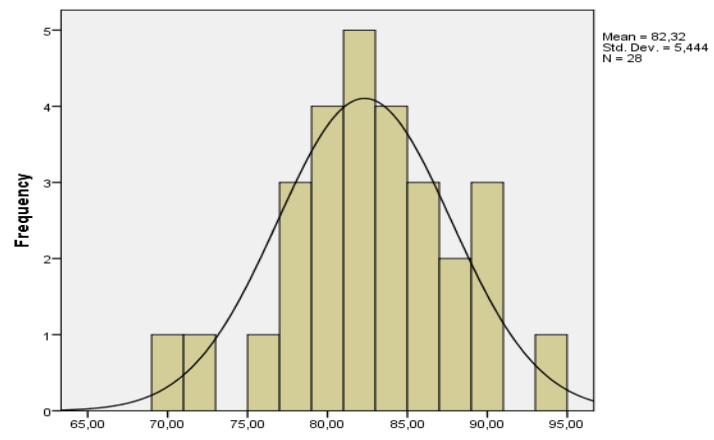

Gambar 1. grafik data kelas VIII E

Dari grafik di atas, dilihat bahwa untuk nilai 70 diperoleh oleh 1 siswa dengan persentase $3,6 \%$, nilai 72 diperoleh oleh 1 siswa dengan persentase $3,6 \%$, nilai 75 diperoleh oleh 1 siswa dengan persentase $3,6 \%$, nilai 78 diperoleh oleh 3 siswa dengan persentase $10,7 \%$, nilai 79 diperoleh oleh 2 siswa dengan persentase $7,1 \%$, nilai 80 diperoleh oleh 2 siswa dengan persentase $7,1 \%$, nilai 81 diperoleh oleh 4 siswa dengan persentase $14,3 \%$, nilai 82 diperoleh oleh 1 siswa dengan persentase $3,6 \%$, nilai 84 diperoleh oleh 4 siswa dengan persentase $14,3 \%$, nilai 85 diperoleh oleh 2 siswa dengan persentase $7,1 \%$, nilai 86 diperoleh oleh 1 siswa dengan persentase 3,6 $\%$, nilai 87 diperoleh oleh 1 siswa dengan persentase $3,6 \%$, nilai 88 diperoleh oleh 1 siswa dengan persentase $3,6 \%$, nilai 89 diperoleh oleh 1 siswa dengan persentase 3,6\%, nilai 90 diperoleh oleh 2 siswa dengan persentase $7,1 \%$, dan nilai 94 diperoleh oleh 1 siswa dengan persentase $3,6 \%$.

Untuk klasifikasi angket "pendidikan karakter menghargai prestasi" siswa kelas VIII E SMP N 18 Kota Jambi, sebagai berikut :

1. Kategori "sangat tidak baik" untuk rentang $25-43,75=0 \%$

2. Kategori "tidak baik" untuk rentang $43,76-62,5=0 \%$

3. Kategori "baik" untuk rentang $62,6-81,25=50 \%$

4. Kategori "sangat baik" untuk rentang $81,26-100=50 \%$

Untuk data kelas VIII F setelah diolah menggunakan alikasi SPSS, diperoleh nilai mean sebesar 85,1000, modus sebesar 79,00 median sebesar 85,0000 , standar deviasi sebesar 5,68937 dengan nilai terendahnya adalah 75,00 dan nilai tertinggi 96,00 . 


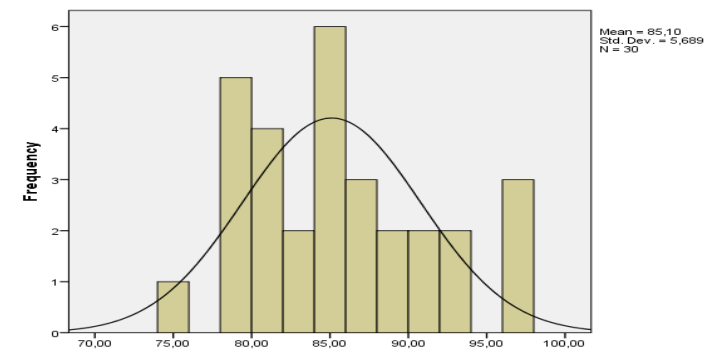

Gambar 2. grafik data kelas VIII F

Dari grafik di atas, dilihat bahwa untuk nilai 75 diperoleh oleh 1 siswa dengan persentase $3,3 \%$, nilai 78 diperoleh oleh 1 siswa dengan persentase $3,3 \%$, nilai 79 diperoleh oleh 4 siswa dengan persentase $13,3 \%$, nilai 80 diperoleh oleh 1 siswa dengan persentase $3,3 \%$, nilai 81 diperoleh oleh 3 siswa dengan persentase $10 \%$, nilai 82 diperoleh oleh 1 siswa dengan persentase $3,3 \%$, nilai 83 diperoleh oleh 1 siswa dengan persentase 3,3\%, nilai 84 diperoleh oleh 2 siswa dengan persentase $2,67 \%$, nilai 85 diperoleh oleh 4 siswa dengan persentase 13,3 $\%$, nilai 86 diperoleh oleh 3 siswa dengan persentase $10 \%$, nilai 88 diperoleh oleh 2 siswa dengan persentase $6,7 \%$, nilai 90 diperoleh oleh 1 siswa dengan persentase 3,3\%, nilai 91 diperoleh oleh 1 siswa dengan persentase $3,3 \%$, nilai 92 diperoleh oleh 1 siswa dengan persentase 3,3\%, nilai 93 diperoleh oleh 1 siswa dengan persentase $3,3 \%$, dan nilai 96 diperoleh oleh 3 siswa dengan persentase $10 \%$.

Untuk klasifikasi angket "pendidikan karakter menghargai prestasi" siswa kelas VIII E SMP N 18 Kota Jambi, sebagai berikut :

1. Kategori "sangat tidak baik" untuk rentang $25-43,75=0 \%$

2. Kategori "tidak baik" untuk rentang $43,76-62,5=0 \%$

3. Kategori "baik" untuk rentang $62,6-81,25=33,3 \%$

4. Kategori "baik" untuk rentang $81,26-100=66,7 \%$

\section{PEMBAHASAN}

Pendidikan memiliki peranan penting dalam kehidupan. Pendidikan itu sendiri adalah suatu proses pembelajaran supaya mendapatkan informasi ataupun pengetahuan. Indikator keberhasilan sistem pendidikan bukan saja diukur dari tingkat pengetahuan siswa. Tatapi, juga memperhatikan aspek karakter siswa.

Pada umumnya, sitem pendidikan di Indonesia, tidak hanya berfokus pada penguasaan aspek pengetahuan saja, tetapi juga berfokus pada pembangunan karakter siswanya. Menurut Zuriah dalam (Kardiyem, 2013: 49), pendidikan karakter sering disamakan dengan pendidikan budi pekerti. Pendidikan budi pekerti merupakan program pengajaran di sekolah yang bertujuan mengembangkan watak atau tabiat siswa dengan cara menghayati nilai-nilai dan keyakinan masyarakat. Berdasarkan keputusan Kemendiknas, terdapat 18 nilainilai karakter bangsa, salah satunya adalah menghargai prestasi.

Prestasi itu sendiri merupakan pencapaian berharga yang diperoleh dengan upaya dirinya sendiri. Seperti yang diketahui, banyak siswa yang kurang memberi 
apresiasi terhadap pencapaian orang lain maupun dirinya sendiri. Seperti contoh, kurangnya apresiasi siswa terhadap penghargaan yang ddapatkan orang lain atau kurangnya rasa percaya diri terhadap kemampuannya sendiri.

Di kecamatan Alam Barajo, Kota Jambi tepatnya di SMP NEGERI 18 Kota Jambi sudah di ajarkan bagaimana siswanya bisa menghargai prestasi orang lain atau teman sendiri. Pendidikan yang khas untuk menanamkan sikap menghargai prestasi melalui kegiatan penghargaan juara dikelas dan juga penghargaan di kegiatan classmeting.

Oleh karena itu, peneliti tertarik untuk mengetahui bagaimana sikap siswa SMP NEGERI 18 Kota Jambi terhadap Pendidikan Karakter menghargai prestasi siswa kelas VIII SMP N 18 Kota Jambi, khususnya kelas VIII E dan VIII F. Penelitian inii dilakukan dengan cara menyebarkan angket kepada para siswa. Hasil peneletian ini berupa data kuantitatif dan di analisis menggunakan dengan menggunakan statistika deskriptif.

Berdasarkan data yang di dapatkan dari hasil penyebaran angket menghargai prestasi siswa kelas VIII E didapatkan nilai rata-rata (mean) sebesar 82,3214 dari 28 responden. Sedangkan untuk nilai tengah (median) didapatkan sebesar 81,5000. Sementara untuk nilai yang sering muncul (modus) didapatkan sebesar 81,00. Untuk standar deviasi didapatkan sebesar 5,44368. Rentang yang didapatkan sebesar 25. Nilai minimum yang didapatkan sebesar 70, dan nilai maksimum yang didapatkan sebesar 94 .

Untuk kelas VIII F didapatkan nilai rata-rata (mean) sebesar 85,1000 dari 32 responden. Sedangkan untuk nilai tengah (median) didapatkan sebesar 85,000. Sementara untuk nilai yang sering muncul (modus) didapatkan sebesar 79,00. Untuk standar deviasi didapatkan sebesar 5,68937. Rentang yang didapatkan sebesar 21 . Nilai minimum yang didapatkan sebesar 75 , dan nilai maksimum yang didapatkan sebesar 96.

Selain itu, penilaian angket karakter menghargai prestasi juga dapat ditinjau dari segi penilaian skala likert. Berdasarkan data yang diperoleh dari kelas VIII E, terdapat $50 \%$ siswa yang menjawab angket dengan kategori "Baik". Terdapat pula $50 \%$ siswa yang menjawab angket dengan kategori "Sangat Baik". Sedangkan untuk kelas VIII F, terdapat 33,7 \% siswa yang menjawab angket dengan kategori "Baik". Terdapat pula $66,7 \%$ siswa yang menjawab angket dengan kategori "Sangat Baik".

\section{KESIMPULAN}

Berdasarkan hasil analisis angket karakter "Menghargai Prestasi" siswa kelas VIII E dan VIII F SMP N 18 Kota Jambi, didapatkan hasil data pada kelas VIII E dengan nilai mean sebesar 82,3214, median sebesar 81,5000, modus sebesar 81,00, standar deviasi sebesar 5,44368, rentang sebesar 25, nilai minimum sebesar 70, dan nilai maksimum sebesar 94. Hal ini juga dibuktikan dengan penilaian skala likert yang menunjukkan bahwa terdapat $50 \%$ siswa yang menjawab angket dengan kategori "Baik" dan terdapat $50 \%$ siswa yang menjawab angket dengan kategori "Sangat Baik". Sedangkan data yang diperoleh pada kelas VIII F menunjukkan bahwa nilai mean dari data tersebut adalah 85,1000 , median sebesar 85,000, modus sebesar 79,00, standar deviasi sebesar 5,68937, rentang sebesar 21 , nilai minimum sebesar 75 , dan nilai maksimum sebesar 96. Hal ini juga dibuktikan dengan penilaian skala likert yang 
menunjukkan bahwa terdapat 33,7 \% siswa yang menjawab angket dengan kategori "Baik" dan terdapat 66,7 \% siswa yang menjawab angket dengan kategori "Sangat Baik". Berdasarkan penjelasan tersebut, dapat disimpulkan bahwa siswa kelas VIII E telah memiliki karakter yang baik dalam menghargai prestasi. Sedangkan untuk siswa kelas VIII F, telah memiliki karakter yang sangat baik dalam menghargai prestasi. Dengan adanya pendidikan karakter menghargai prestasi, siswa dapat menanamkan sifat rendah hati,tidak sombong,termotivasi untuk beraktivitas dan munculnya ide-ide baru siswa tersebut.

\section{SARAN}

Dalam penelitian ini, peneliti menyadari bahwa penerapan pendidikan karakter sangat penting untuk diterapkan kepada siswa pada setiap jenjang pendidikan. Oleh karena itu, peneliti berharap adanya peningkatan kesadaran siswa dalam menghargai prestasi.

Menerapkan pendidikan karakter menghargai prestasi dalam sekolah perlu dukungan dari berbagai pihak terkait.Khususnya dalam dunia pendidikan yang terkait dengan kepala sekolah memiliki peran penting untuk mendorong pembentukan pendidikan karakter menghargai prestasi. Kemudian gurujuga harus menguasai materi yang ada dalam kurikulum pendidikan karakter menghargai prestasi, memadukan dalam mata pelajaran yang terkait, berkoordinasi dengan guru lainnya dan menggunakan metode pembelajaran yang sesuai agar siswa tertarik untuk belajar serta merealisasikan dalam kehidupan.

DAFTAR RUJUKAN

Amir, Rudi. 2017. Membangun Karakter dalam Perayaan Budaya Lokal di Kabupaten Takalar. Jurnal Publikasi Pendidikan, 7(3), 127-133.

Fauzi, Achmad Ryan., Zainuddin, dan Atok, Rosyid Al. (2017). Penguatan Karakter Rasa Ingin Tahu dan Peduli Sosial Melalaui Discovery Learning. Jurnal Teori dan Praksis Pembelajaran IPS, 2(2), 27-36.

Febrianshari, Deddy dkk. 2018. Analisis Nilai-Nilai Pendidikan Karakter dalam Pembuatan Dompet Punch Zaman Now. Jurnal Pemikiran dan Pengembangan SD, 6(1), 88-95.

Kardiyem. 2013. Internalisasi Pendidikan Karakter dalam Akuntansi (Inspirasi)

Diary (Solusi Konservasi Moral). Jurnal Dinamika Akuntansi, 5(1), 47-54.

Kurniawan, D., A., dkk. 2018. Evaluasi Sikap Siswa SMP terhadap IPA di Kabupaten Muaro Jambi. Jurnal Ilmiah DIDAKTIKA. Vol 19 No. 1. ISSN 124-139.

Kurniawati, Rizki dan Irsyadillah. 2018. Analisis Nilai Karakter dalam Teks Cerita Buku Pelajaran Siswa Sekolah Dasar. Master Bahasa, 6(2), 103114.

Nisa, Zulia. K. 2019. Pengembangan Pendidikan Lingkungan Hidup Di Pondok Pesantren Kabupaten Blitar. Briliant: Jurnal Riset dan Konseptual, 4 (1) 105-113 
Nurjannah, Siti. (2017). Penanaman Karakter Kerja Keras dan Menghargai Prestasi Pada Siswa. Skripsi. Tidak diterbitkan. Fakultas Keguruan dan Ilmu Pendidikan Universitas Muhammadiyah Surakarta.

Sani, R, A. 2014. Pembelajaran Saintifik untuk Implikasi Kurikulum 2013. Jakarta: Bumi Aksara. 